\title{
The Development of Sociocultural Malay-Based on Folklore Teaching Materials for Class X at SMA N 1 Percut Sei Tuan Deli Serdang
}

\author{
Junifran', Rosliani \\ ${ }^{1}$ Postgraduate Program Indonesian Language and Literature Education, Universitas Prima Indonesia \\ ${ }^{2}$ Balai Bahasa Sumatera Utara \\ junifran.malau@gmail.com,rosliani.12@gmail.com
}

\section{Abstract}

This study aims to determine the results of the development of sociocultural-based folklore teaching materials in class X at SMA Negeri 1 Percut Sei Tuan. SMA Negeri 1 Percut Sei Tuan is a public school in the city of Medan and is located in Percut Sei Tuan Village. The teaching materials developed are modules. This research is a development research based on the development model from Borg and Gall. The subjects consisted of material experts, design experts, Indonesian language teachers, and class X students of SMA Negeri 1 Percut Sei Tuan. The results showed that (1) the sociocultural values contained in the folklore of Putri Hijau and Hikayat Si Khalib include, (a) religious values, $(b)$ solidarity values, $(c)$ the value of unity, $(d)$ the value of struggle, and (e) cultural values. (2) Validation from material experts includes the feasibility of content getting $92.68 \%$ in the "very good" category, $94.19 \%$ presentation eligibility acquisition in the "very good" category, and $93.13 \%$ language eligibility acquisition in the "very good" category. The validation from design experts with an average of $81.81 \%$ with "good" criteria. Overall, the teacher responses with an average of $92.26 \%$ on the "very good" criteria. Individual trials with an average percentage of $75.6 \%$ with the criteria "good enough". Small group trials with an average percentage of $83.77 \%$ with "good" criteria, and limited field trials with an average percentage of $91.80 \%$ with "very good" criteria. (3) The results of learning to rewrite folklore before using the module obtained $61.97 \%$, while the learning outcomes of the folk tale rewriting test after using the module obtained $82.40 \%$. The difference obtained is $18.58 \%$ from before and after using the module. This proves that the folklore teaching materials based on the sociocultural Malay are increasing.
Keywords

teaching materials; folklore; sociocultural

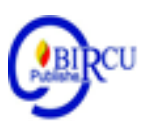

\section{Introduction}

Education is the most important thing for the development of a nation's civilization. In setting up a stable education system, of course, it takes a long and tiring process to achieve high quality standards. The government has carried out improvements in order to improve the quality of education at various levels to achieve the goals of national education and institutions engaged in education have made various reforms and improvements on a national and global scale. One of the improvements the government has taken is the change of the Education Unit Level Curriculum (KTSP) to the 2013 Curriculum. The launch of the 2013 curriculum is very meaningful for a change in the educational paradigm so that through the 
2013 curriculum, education will be directed to develop the potential of students to have religious spiritual power, self-introduction, personality, intelligence, noble character and personal skills.

As educators, teachers have a heavy duty to manage and develop learning resources as contained in the National Education System Law No. 20 of 2013 article 39, namely education personnel in charge of carrying out administration, management, development, supervision, and technical services to support the educational process in educational units. Likewise, students are expected to have better attitudes, skills and knowledge competencies and in the end it will create a learning society, where every member of society has the right to education (education for all) and become a lifelong learning (long life education). (Quoted from the institutional.ristekdikti.go.id page)

Better demands and hopes for the education system then have implications for curriculum changes, especially the Indonesian language curriculum. Changes in the Indonesian language curriculum need to pay attention to several things that influence one another, namely textbooks, assessment procedures used from policies issued by the government. Alice (Sanjaya, 2011: 71) suggests the following: "(1) The curriculum must be adapted to children's development, (2) The content of the curriculum includes skills, knowledge and attitudes that are considered useful for the present and future, (3) Children should be placed as learning subjects who try to learn on their own ". This means that students must be encouraged to carry out various learning activities, not just receiving information from the teacher.

\section{Review of Literatures}

One of the subjects in the 2013 curriculum taught at SMA N 1 Percut Sei Tuan is folklore found in Basic Competency 3.7 "identifying the values and content contained in folklore (saga) both oral and written." This basic competency aims to enable students to identify the values and content contained in folklore (saga) both oral and written. Folklore is one of the literary works that can specifically be used as teaching material and helps students to recognize local wisdom and understand its meaning as a source of moral teaching. Rangkuti (2020) states that development of teaching materials is used as a way to identify, develop, and evaluate learning content and strategies.

The local wisdom possessed by each region certainly has positive values for the development and character of children and can foster a love for regional culture. Folklore can also introduce the culture of the archipelago to students and can also take advice from the folklore as a socio-cultural education. This study seeks to contribute to the development of sociocultural Malay-based folklore so that it can be used as a source of learning material for Indonesian language and literature so that folklore based on sociocultural Malay can be used as an alternative source of teaching materials by teachers during the learning process. The data obtained shows that student learning outcomes in understanding folklore are still lacking, especially regarding Malay folklore.

These results are supported by previous research conducted by Novianti, (2015) in her research entitled "Development of Historical Teaching Materials in the Form of Folk Stories as a Form of Local Wisdom". The low awareness of teachers in exploring local genius (local wisdom) as teaching material makes students unable to recognize their own cultural heritage, especially as a local pride is still very far from internalizing. For example, folklore is one of the materials and components for developing teaching materials that teachers do not really pay attention to in teaching. 
Another research conducted by Nugroho, Agung (2013) entitled "Development of Literary Teaching Materials Based on Folklore Musi Rawas Class V SD Negeri Karyadadi, Musi Rawas Regency". So far, literary learning activities at SD Negeri Karyadadi are only guided by the teacher's handbook without any effort to bring learning material closer to students. None of the literary books that have been used have been oriented towards Musi Rawas literature, but tend to be well-known in the archipelago so that students do not know that in their area there are also literature worthy of study. This is what makes learning activities less attractive, less motivating students and less closer to students in regional literature which aims to increase regional love and interest in learning literature. Therefore, the researcher intends to provide a new perspective in learning folklore oriented to Malay folklore, so that students know that in their area there are also folk tales that are worth knowing and studying.

Another factor that motivates the writer to develop folklore teaching materials based on Malay socioculturalism is wanting to provide teaching experience to Indonesian language teachers, especially at SMA N 1 Percut Sei Tuan so that they are able to process teaching material resources in their respective areas, considering Percut Sei Tuan is an area close to Malay culture. In addition to instilling a sense of love for local culture, the development of teaching materials will also make learning activities more varied, which leads to the achievement of competency standards and basic competencies in each school, in accordance with the principles of developing teaching materials according to Prastowo, (2011: 58), namely , relevance (suitability), consistency (rarity), and adecuacy (adequacy).

Teaching material as a learning device is a reference used by teachers in teaching a subject matter and the procedure for assessing the procedures used to see the results of a learning process. Learning outcomes refer to three aspects, namely attitudes, skills and knowledge. Between teaching materials and assessment procedures must refer to the Graduate Competency Standard (SKL). With teaching materials a teacher can diagnose and evaluate students. The teacher can also provide exercises to provide reinforcement and previously learned skills and can also provide enrichment that is considered important and new for students.

Teaching materials as one of the learning tools used are sometimes not in accordance with the learning model used by the teacher. The suitability between the teaching materials and the learning model used will further increase the effectiveness of the learning carried out by the teacher. Zainal (2013: 41) states that: "Using tools and various ways to arouse enthusiasm, including using the environment as a learning resource to make learning interesting, fun and suitable for students".

The world of education in Indonesia applies the 2013 curriculum, so the teaching materials used must be in accordance with needs, namely teaching materials related to the 2013 curriculum. Indonesian Language learning is part of the 2013 curriculum which emphasizes the importance of balancing competencies in attitudes, knowledge, and skills, (Nazila, 2020). Teaching materials based on the 2013 curriculum have a sociocultural-based character with an integrated approach. Indonesian language learning in the 2013 curriculum is oriented towards text-based learning. This can be seen in the core competencies and basic competencies, especially in the basic competencies of class X Senior High School which are presented in this study, namely the folklore of Putri Hijau and Hikayat Si Kholib (Malay stories that are closely related to the life of the Deli Serdang community). Putri Hijau's story is a typical Malay Maimun story that is deeply rooted in the life of the Malay community in Medan. The legendary story of Hikayat Si Kholib is a fragment of a folk tale that is almost timeless from the memory of its owner in Tanjung Beringin, Serdang Bedagai. 


\section{Research Method}

This type of research is development research (Research and Development), namely the development of sociocultural-based folklore teaching materials for high school grade $\mathrm{X}$ level. According to Sugiyono (2016: 297), research and development methods are research methods used to produce certain products and test product effectiveness. the.

The researcher adapted the development applied by Borg and Gall on the grounds that the development design had the aim of developing and validating the product. The development of teaching materials is arranged in a programmed manner with preparation and planning in the following steps:

1) Research and information gathering (literature review, Core Competencies (CC) and Basic Competencies (BC), and identifying problems);

2) Planning for the development of sociocultural-based folklore teaching materials for class $X$ at SMA Negeri 1 Percut Sei Tuan;

3) Developing an introductory form of sociocultural based folklore teaching materials;

4) Initial field test (expert validation);

5) First revision of the main product based on expert validator suggestions;

6) Individual try out (individual group questionnaire by 3 students with characteristics of high, medium, and low ability); Assessment questionnaires are given to individual users with the aim of knowing the validity of the product after being repaired based on a review consisting of three students. The inputs from these individual trials are then used as a basis for making improvements to the product.

7) Second revision of the product if revision is required;

Small group trials (9 students), using a questionnaire. If there are deficiencies that need to be fixed from the product being developed, revisions will be made;

8) Third revision of the results of small group trials if necessary;

Limited field group trials (32 students) namely class $\mathrm{X}$ at SMA Negeri 1 Percut Sei Tuan using a questionnaire.

9) Fourth revision of the product if it still exists, analyzes and processes data, makes conclusions;

10) The final product of sociocultural-based folklore teaching materials, namely modules that have been developed and ready to be applied to folklore learning activities, to help students improve their understanding of the material being taught. The steps for developing sociocultural-based folklore teaching materials can be seen in Figure 1 as follows.

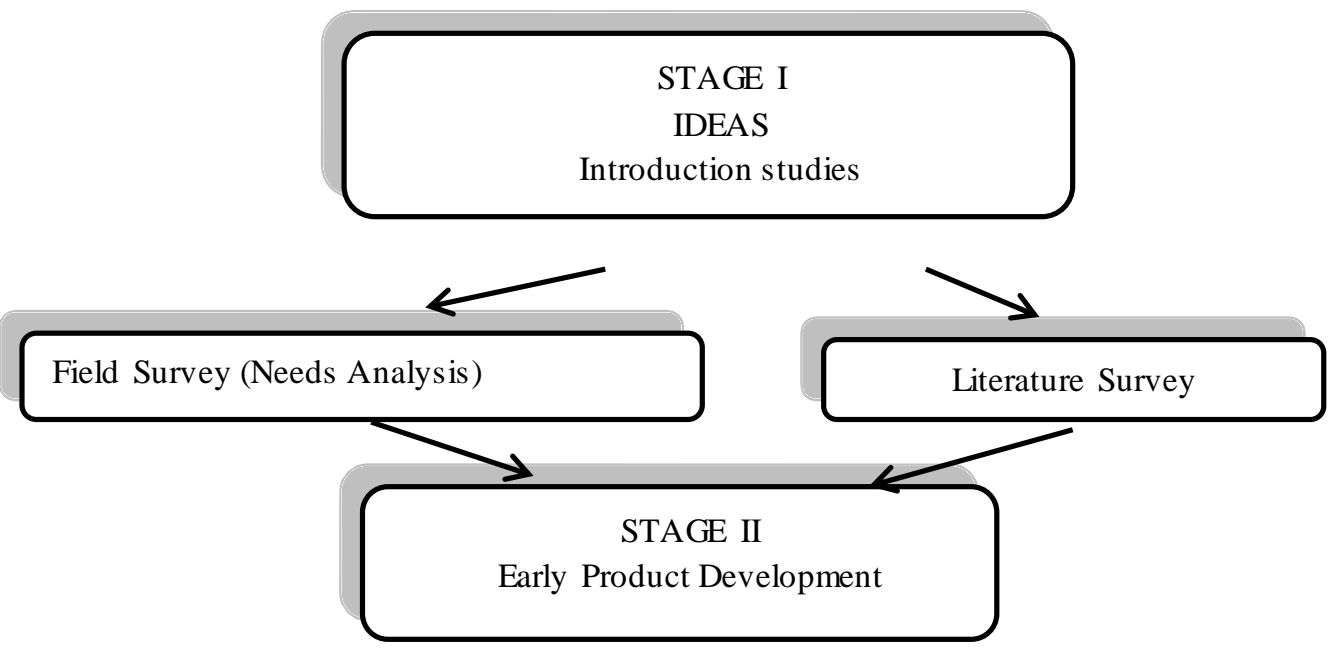




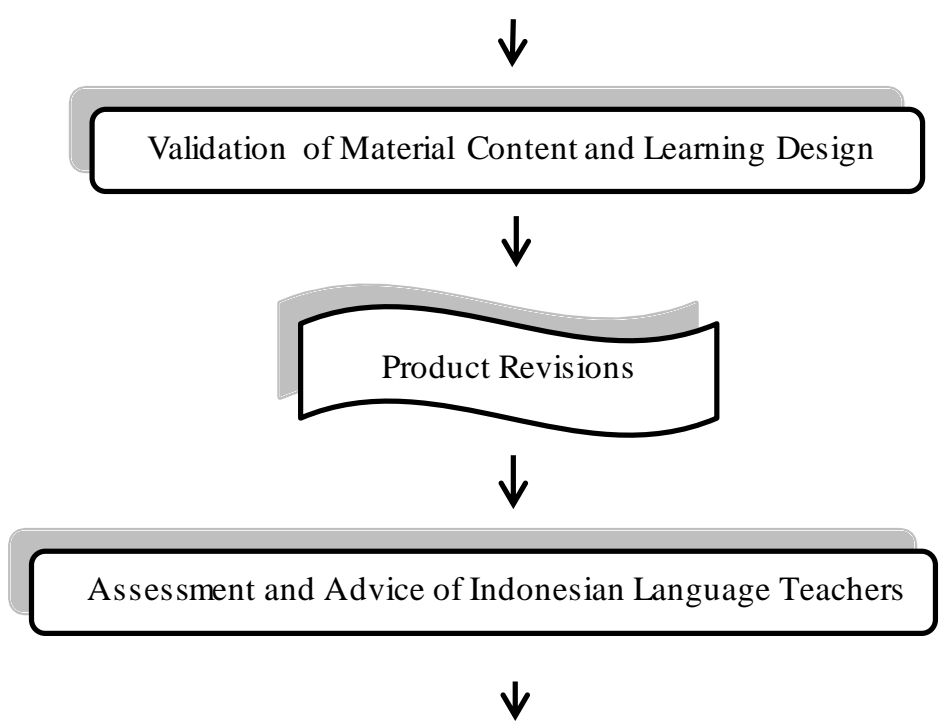

The final product that has been developed and is ready to use is sociocultural-based folklore teaching materials (modules)

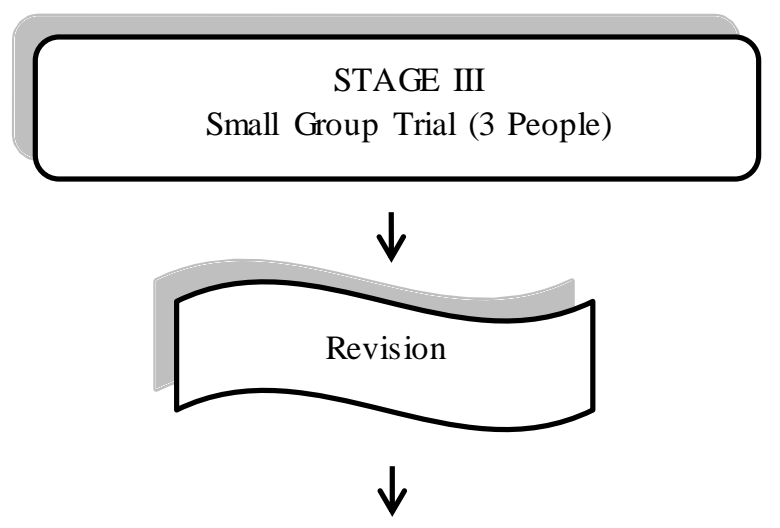

Limited Field Test (9 People)
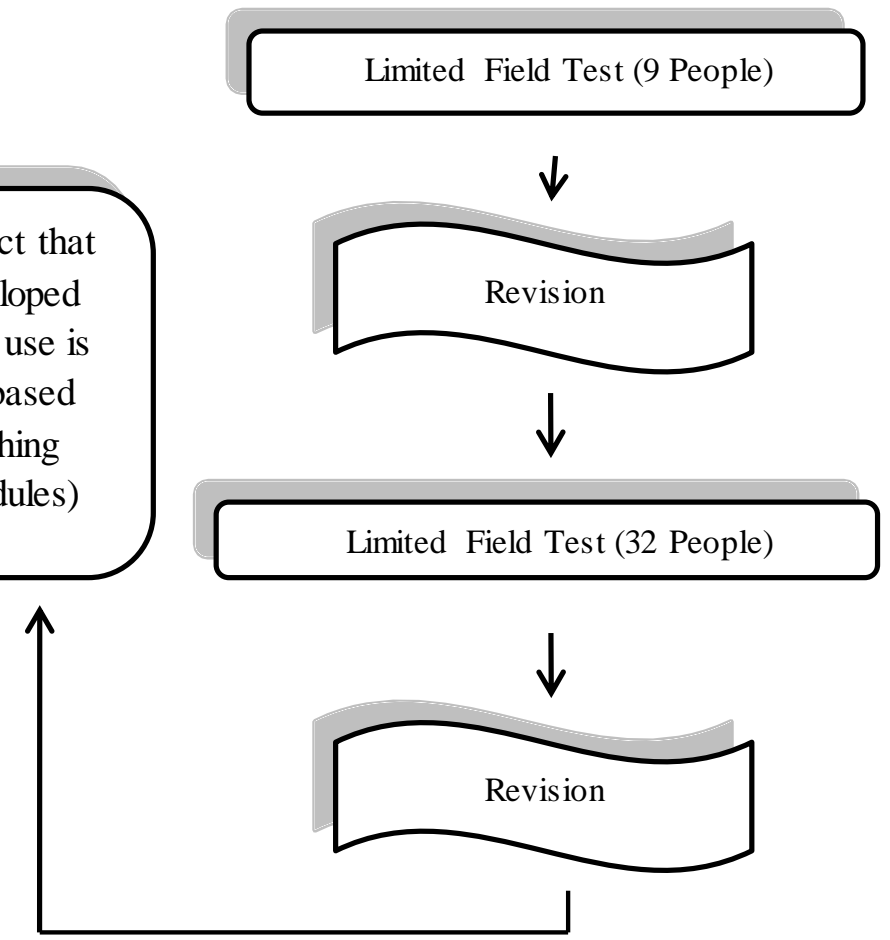

Figure 1. Research and Development Flow Design 


\section{DISCUSSION}

\subsection{Sociocultural Based Folk Stories}

\section{BASIC COMPETENCIES}

3.7 Identifying the values and content contained in folklore (saga), both oral and written

4.7 Retelling the contents of the folk story (hikayat) that was heard and read

3.8 Comparing values and language of folklore and short stories

4.8 Developing folk tales (hikayat) into short stories by paying attention to content and values

\section{INDICATORS}

1. Able to explain the meaning of folklore

2. Able to explain the characteristics of folklore

3. Able to explain content and values in folklore

4. Able to explain the style of folklore

5. Able to explain archaic words (ancient) in folklore

6. Able to explain the elements of folklore

\section{A. INTRODUCTION}

This section contains the competencies that students will achieve in teaching materials, namely sociocultural-based folklore. Furthermore, this section also discusses a brief explanation of the name and scope of the module content, learning outcomes to be achieved, the benefits of these competencies in the learning process and life in general, the steps that must be taken to learn the module correctly, and equipment ( such as facilities / infrastructure / facilities that must be prepared according to learning needs.

\section{B. LEARNING}

\section{LEARNING ACTIVITIES 1}
A. Introduction (Explaining the objectives based on BC 3.7 and 4.7)
B. Definition of folklore
C. Characteristics of folklore
D. Content and values of the folklore
E. Summary
F. Exercise 
A. LEARNING ACTIVITIES 2

A. Introduction (Explaining the objectives based on BC 3.8 and 4.8)

B. Folklore style

C. The archaic word (ancient) in folk tales

D. Elements of folklore

E. Summary

F. Exercise

B. LEARNING ACTIVITIES 3
A. Introduction
B. Definition of sociocultural based learning
C. Sociocultural values in the folklore of the Legend of Putri Hijau and Hikayat Si Kholib
D. Active experimental stage
E. Summary
F. Exercise

C. EVALUATION

Evaluation techniques or methods must be adapted to the domain (domain) being assessed, as well as the success indicators referred to, both in the cognitive, psychomotor and attitudinal domains.

D. ANSWER KEY

Contains answers to questions from tests given in each learning activity and evaluation of competency achievement, equipped with as sessment criteria for each test item.

\section{E REFERENCES}

All references / libraries are used as references when preparing teaching materials (modules)

Figure 2. Sociocultural Based Learning Material Design (Module)

\subsection{Result}

\section{a. The Result of Feasibility Test for the Development of Sociocultural Based Folklore} Teaching Materials

The process of implementing the sociocultural-based development of folk cerista teaching materials is carried out in stages. The first stage is to analyze the problems and needs at SMA Negeri 1 Percut Sei Tuan which is the background of the development research problem by distributing a questionnaire for 2 teachers and 32 students at the school by first outlining the definitions of the teaching materials in the questionnaire so that they have an overview of the questions in The questionnaire presented in the needs analysis was carried out at the initial observation stage. The needs analysis data can be seen in table 1 below.

Tabel 1. Needs Analysis Data

\begin{tabular}{|c|l|c|c|c|c|c|}
\hline \multirow{2}{*}{ No. Questions } & \multirow{2}{*}{ Answers } & \multicolumn{2}{|c|}{ Percentage } \\
\cline { 4 - 6 } & & & Teachers & Students & Total & \\
\hline 1. & $\begin{array}{l}\text { Get to know the } \\
\text { sociocultural-based } \\
\text { folklore module }\end{array}$ & Yes & 2 & 3 & 5 & $14,7 \%$ \\
\cline { 3 - 6 } & No & 0 & 29 & 29 & $85,2 \%$ \\
\hline 2. & $\begin{array}{l}\text { Using a sociocultural-based } \\
\text { folklore module }\end{array}$ & Yes & 0 & 2 & 2 & $5,88 \%$ \\
\cline { 3 - 6 } & No & 2 & 30 & 32 & $94,1 \%$ \\
\hline 3. & Requires a sociocultural & Yes & 2 & 30 & 32 & $94,1 \%$ \\
\hline
\end{tabular}




\begin{tabular}{|c|l|l|l|l|l|l|}
\hline & based folklore module & No & 0 & 2 & 2 & $5,88 \%$ \\
\hline 4. & $\begin{array}{l}\text { The sociocultural-based } \\
\text { folklore learning modul } \\
\text { whose contents are as in } \\
\text { the Yes }\end{array}$ & & 2 & 31 & 33 & $97 \%$ \\
$\begin{array}{l}\text { described above in the } \\
\text { learning process will help } \\
\text { you in learning activities }\end{array}$ & No & 0 & 1 & 1 & $2,9 \%$ \\
\hline 5. & $\begin{array}{l}\text { The sociocultural-based } \\
\text { folklore learning module } \\
\text { whose content is in the } \\
\text { meaning described above is } \\
\text { effectively used in learning } \\
\text { activities }\end{array}$ & Yes & 0 & 32 & 32 & $100 \%$ \\
\hline
\end{tabular}

Based on the table above regarding the needs analysis by teachers and students, the following conclusions are obtained:

a. Most of the students $85.2 \%$ stated that they were not familiar with the learning module in the form of a module, while all teachers and a small proportion of students (14.8\%) stated that they were familiar with teaching materials in the form of modules.

b. The majority of students $94.1 \%$ stated that they were not familiar with socioculturalbased modules, while a small proportion of students (5.8\%) stated that they were familiar with sociocultural-based modules.

c. Most of the $94.1 \%$ students and teachers need sociocultural-based modules in the learning process, while $(5.8 \%)$ do not.

d. The majority of students $97 \%$ stated that the sociocultural-based module helped in the learning process, while a small proportion of students (2.9\%) said they did not need a sociocultural-based module.

e. All teachers and students stated that the sociocultural-based module was very effective in understanding folklore learning;

Based on the needs analysis, it was concluded that the development of teaching materials was needed by teachers and students in the learning process to improve the quality of learning. Furthermore, the researchers planned teaching materials in the form of folklore modules.

Based on the results of the assessment by the validator above on the feasibility of the content, it shows that the teaching materials that have been developed are very good criteria. Sociocultural-based folklore teaching materials for class X MA students that were developed obtained the feasibility of content with an average score of $93.38 \%$ with the criteria of "very good".

Presentation feasibility consists of five sub-components which include: a) presentation technique, b) presentation of learning, and c) completeness of presentation. The overall average number of presentation feasibility is declared "very good" with a total percentage of 95.19\%. Data from material expert validation on presentation feasibility can be seen in table 2 below. 
Tabel 2. Feasibility Test Results for Sociocultural-Based Folklore Teaching Materials for the Feasibility Aspects of Presentation by Material Experts

\begin{tabular}{|c|c|c|c|c|c|c|}
\hline \multirow[b]{2}{*}{$\begin{array}{l}\text { Component } \\
\text { Subdivision }\end{array}$} & \multirow[b]{2}{*}{ Assessment Indicators } & \multicolumn{2}{|c|}{ Respondents } & \multirow[b]{2}{*}{$\begin{array}{l}\text { Total } \\
\text { Score }\end{array}$} & \multirow[b]{2}{*}{$\begin{array}{c}\text { Percentage } \\
\text { average }\end{array}$} & \multirow[b]{2}{*}{ Criteria } \\
\hline & & 1 & 2 & & & \\
\hline \multirow[t]{2}{*}{$\begin{array}{l}\text { A. Presentation } \\
\text { technique }\end{array}$} & $\begin{array}{ll}\text { 1. } & \text { Systematic } \\
\text { Consistency of } \\
\text { Serving in } \\
\text { Learning Activities }\end{array}$ & 4 & 3 & 7 & 87,5 & Very Good \\
\hline & 2. Concept coherence & 4 & 3 & 7 & 87,5 & Very Good \\
\hline \multirow[t]{3}{*}{$\begin{array}{l}\text { B. Presentation } \\
\text { of Learning }\end{array}$} & $\begin{array}{ll}3 . & \text { Student } \\
& \text { Involvement }\end{array}$ & 4 & 4 & 8 & 87,5 & Very Good \\
\hline & 4. Student Centered & 4 & 4 & 8 & 100 & Very Good \\
\hline & $\begin{array}{ll}\text { 5. } & \text { Stimulating } \\
\text { Students' Ability } \\
\text { to Solve } \\
\text { Problems } \\
\text { through } \\
\text { Illustrations }\end{array}$ & 3 & 4 & 7 & 87,5 & Very Good \\
\hline \multirow[t]{8}{*}{$\begin{array}{l}\text { C. Completeness } \\
\text { of } \\
\text { Presentation }\end{array}$} & $\begin{array}{ll}6 . & \text { Examples of } \\
\text { Questions in Each } \\
\text { Learning Activity }\end{array}$ & 3 & 4 & 7 & 87,5 & Very Good \\
\hline & $\begin{array}{l}\text { 7. Exercise questions } \\
\text { at the end of each } \\
\text { learning activity }\end{array}$ & 3 & 4 & 7 & 87,5 & Very Good \\
\hline & $\begin{array}{l}\text { 8. Key to the answer } \\
\text { to the practice } \\
\text { questions }\end{array}$ & 4 & 4 & 8 & 100 & Very Good \\
\hline & 9. $\quad$ Introduction & 4 & 4 & 8 & 100 & Very Good \\
\hline & 10. Table of Contents & 4 & 4 & 8 & 100 & Very Good \\
\hline & 11. Glossary & 4 & 4 & 8 & 100 & Very Good \\
\hline & 12. References & 4 & 4 & 8 & 100 & Very Good \\
\hline & 13. Summary & 4 & 4 & 8 & 100 & Very Good \\
\hline \multicolumn{2}{|l|}{ Total } & 49 & 50 & 99 & 1.225 & \multirow{2}{*}{ Very Good } \\
\hline & Average & & & & 95,19 & \\
\hline
\end{tabular}

Based on the results of the assessment by the validator above on the feasibility of presentation, it shows that the teaching materials that have been developed are very good criteria. The teaching material in the form of a sociocultural-based folklore module for grade $\mathrm{X}$ senior high school students that was developed obtained the feasibility of presentation with an average score percentage of $95.19 \%$ on the "very good" criteria. 
Tabel 3. Feasibility Test Results for Sociocultural-Based Folklore Teaching Materials for Language Feasibility Aspects by Material Experts

\begin{tabular}{|c|c|c|c|c|c|c|}
\hline \multirow{2}{*}{$\begin{array}{l}\text { Component } \\
\text { Subdivision }\end{array}$} & \multirow{2}{*}{$\begin{array}{l}\text { Assessment } \\
\text { Indicators }\end{array}$} & \multicolumn{2}{|c|}{ Respondents } & \multirow{2}{*}{$\begin{array}{l}\text { Total } \\
\text { Score }\end{array}$} & \multirow{2}{*}{$\begin{array}{c}\text { Average } \\
\text { Percentage }\end{array}$} & \multirow[t]{2}{*}{ Criteria } \\
\hline & & 1 & 2 & & & \\
\hline \multirow[t]{3}{*}{$\begin{array}{l}\text { A. } \begin{array}{l}\text { Straightfor } \\
\text { ward }\end{array}\end{array}$} & $\begin{array}{l}\text { Accuracy of } \\
\text { Sentence } \\
\text { Structure }\end{array}$ & 4 & 3 & 7 & 87,5 & Very Good \\
\hline & $\begin{array}{l}\text { 2. The } \\
\text { Effectiveness } \\
\text { of Sentences }\end{array}$ & 4 & 3 & 7 & 87,5 & Very Good \\
\hline & $\begin{array}{l}\text { 3. Standardizatio } \\
\mathrm{n} \text { of the term }\end{array}$ & 4 & 3 & 7 & 87,5 & Very Good \\
\hline \multirow[t]{2}{*}{$\begin{array}{l}\text { B. Communica } \\
\text { tive }\end{array}$} & $\begin{array}{ll}\text { 4. } & \begin{array}{l}\text { Readability of } \\
\text { messages or } \\
\text { information }\end{array} \\
\end{array}$ & 4 & 4 & 8 & 100 & Very Good \\
\hline & $\begin{array}{ll}\text { 5. } & \text { Accurate } \\
\text { Language } \\
\text { Usage }\end{array}$ & 4 & 3 & 7 & 87,5 & Very Good \\
\hline \multirow[t]{2}{*}{$\begin{array}{ll}\text { C. Dialogical } \\
\text { and } \\
\text { Interactive }\end{array}$} & $\begin{array}{l}\text { 6. Motivation or } \\
\text { Information } \\
\text { Ability }\end{array}$ & 3 & 4 & 7 & 87,5 & Very Good \\
\hline & $\begin{array}{ll}\text { 7. } & \text { Encourage } \\
\text { Critical } \\
\text { Thinking }\end{array}$ & 3 & 4 & 7 & 87,5 & Very Good \\
\hline \multirow[t]{2}{*}{\begin{tabular}{ll} 
D. & \multicolumn{3}{l|}{ Conformity } \\
with the \\
Level of \\
Developme \\
nt & of \\
Students &
\end{tabular}} & $\begin{array}{l}\text { 8. Suitability } \\
\text { with the } \\
\text { Intellectual } \\
\text { Development } \\
\text { of Students }\end{array}$ & 4 & 4 & 8 & 100 & Very Good \\
\hline & $\begin{array}{l}\text { 9. Suitability with } \\
\text { the Level of } \\
\text { Emotional } \\
\text { Development } \\
\text { of Students }\end{array}$ & 4 & 4 & 8 & 100 & Very Good \\
\hline \multirow[t]{2}{*}{$\begin{array}{ll}\text { E. } & \text { Cluster and } \\
\text { Flow of } \\
\text { Thought }\end{array}$} & $\begin{array}{l}\text { 10. Cluster and } \\
\text { cohesiveness } \\
\text { between } \\
\text { learning } \\
\text { activities }\end{array}$ & 4 & 4 & 8 & 100 & Very Good \\
\hline & $\begin{array}{l}\text { 11. Coherence } \\
\text { and coherence } \\
\text { between } \\
\text { paragraphs }\end{array}$ & 4 & 4 & 8 & 100 & Very Good \\
\hline \multirow{2}{*}{\begin{tabular}{ll|} 
F. Use of \\
Terms, \\
Symbols \\
and Icons
\end{tabular}} & $\begin{array}{l}\text { 12. Consistent } \\
\text { Use of Terms }\end{array}$ & 4 & 4 & 8 & 100 & Very Good \\
\hline & $\begin{array}{l}\text { 13. Consistent } \\
\text { use of } \\
\text { symbols or } \\
\text { icons }\end{array}$ & 4 & 4 & 8 & 100 & Very Good \\
\hline \multicolumn{2}{|l|}{ Total } & 50 & 48 & 99 & 1.225 & \multirow{2}{*}{ Very Good } \\
\hline Average & & & & & 94,23 & \\
\hline
\end{tabular}


Based on the results of the assessment by the validator above on the feasibility of language, it shows that the teaching materials that have been developed are very good criteria. Teaching materials in the form of sociocultural-based folklore modules for class $\mathrm{X}$ of Senior High School which were developed obtained language assessment with an average score percentage of $94.23 \%$ with the criteria of "very good".

\section{b. Results of Student Responses to Teaching Materials in Small Group Trials}

The trial was carried out on nine students with high, medium, and low abilities to find out more about students' perceptions of the developed and revised products from their weaknesses after individual trials. Data on the results of student responses in small group trials to the modules that have been developed can be seen in table 4 below.

Tabel 4. Small Group Trial Results (9 Students) on Sociocultural-Based Folklore Teaching Materials

\begin{tabular}{|c|l|c|c|}
\hline No & \multicolumn{1}{|c|}{ Indicators } & Average (\%) & Criteria \\
\hline 1 & This module makes me happy learning it. & 88,88 & Good \\
\hline 2 & $\begin{array}{l}\text { The presentation of material in the module starts from easy } \\
\text { to difficult material and from concrete to abstract. }\end{array}$ & 91,66 & Good \\
\hline 3 & This module creates questions that encourage me to think. & 75 & Good \\
\hline 4 & $\begin{array}{l}\text { The presentation of the material in this module encouraged } \\
\text { me to discuss it with other friends. }\end{array}$ & 83,33 & Good \\
\hline 5 & The material for this module stimulates my curiosity. & 86,11 & Good \\
\hline 6 & $\begin{array}{l}\text { This module contains a formative test that can test how far } \\
\text { I understand the sociocultural-based folklore material. }\end{array}$ & 86,11 & Good \\
\hline 7 & The language used is simple and easy to understand. & 88,88 & Good \\
\hline 8 & The letters used are simple and easy to read. & 88,88 & Good \\
\hline 9 & $\begin{array}{l}\text { By using this module, it will make my learning more } \\
\text { focused and coherent. }\end{array}$ & 83,33 & Good \\
\hline 10 & This module looks interesting. & 88,88 & Good \\
\hline 11 & Using this module can increase the desire to learn. & 86,11 & Good \\
\hline 12 & $\begin{array}{l}\text { Using this module can make learning to rewrite folk tales } \\
\text { less boring. }\end{array}$ & 80,55 & $\mathbf{8 4 , 7 2}$ \\
\hline
\end{tabular}

The results of small group trials on students' perceptions of the teaching materials that have been developed show an average percentage of $84.72 \%$ with "good" criteria. These results were obtained after improvements and revisions from individual trials so that the teaching materials were revised again from the composition of the material and the use of language that was easier for students to understand.

\section{c. Results of Student Responses to Teaching Materials in Limited Field Trials}

The trial was conducted on 32 students with high, medium, and low abilities. Limited field trials produce data used to find out how the product benefits students. The data on the results of student responses in limited field trials to modules that have been developed concluded that the module was included in the "very good" criteria with an average score percentage of $91.60 \%$. Data on the results of student responses to limited field trials to the module can be seen in table 5 below. 
Tabel 5. The Results of Field Trials are Limited to Sociocultural-Based Folklore Teaching Materials

\begin{tabular}{|c|c|c|c|}
\hline No & Indicators & Average (\%) & Criteria \\
\hline 1 & This module makes me happy learning it. & 92,96 & Very Good \\
\hline 2 & $\begin{array}{l}\text { The presentation of material in the module starts from easy } \\
\text { to difficult material and from concrete to abstract. }\end{array}$ & 91,40 & Very Good \\
\hline 3 & This module creates questions that encourage me to think. & 92,18 & Very Good \\
\hline 4 & $\begin{array}{l}\text { The presentation of the material in this module encouraged } \\
\text { me to discuss it with other friends. }\end{array}$ & 92,96 & Very Good \\
\hline 5 & The material for this module stimulates my curiosity. & 89 & Good \\
\hline 6 & $\begin{array}{l}\text { This module contains a formative test that can test how far I } \\
\text { understand the sociocultural-based folklore material. }\end{array}$ & 89 & Good \\
\hline 7 & The language used is simple and easy to understand. & 92,18 & Very Good \\
\hline 8 & The letters used are simple and easy to read. & 91,40 & Very Good \\
\hline 9 & $\begin{array}{l}\text { By using this module, it will make my learning more } \\
\text { focused and coherent. }\end{array}$ & 91,40 & Very Good \\
\hline 10 & This module looks interesting. & 96 & Very Good \\
\hline 11 & Using this module can increase the desire to learn. & 90,62 & Very Good \\
\hline 12 & $\begin{array}{l}\text { Using this module can make learning to rewrite folk tales } \\
\text { less boring. }\end{array}$ & 89,84 & Good \\
\hline & Average Amount & 91,60 & Very Good \\
\hline
\end{tabular}

The results of limited field trials on students' perceptions of the teaching materials that have been developed show an average percentage of $91.60 \%$ with "very good" criteria. This means that the teaching materials developed have increased development and can meet the demands of learning needs. This limited field trial assessment is the final stage of testing teaching material products in the form of sociocultural-based folklore teaching materials at class X.

\section{d. Product Data Analys is}

The results of the validation and assessment by material experts and design experts on each aspect of the overall assessment are determined by the average score of each criterion. The results of the assessment are analyzed to determine whether or not the module being developed is appropriate. The average percentage of the results of assessments by material experts, design experts, teacher assessments, as well as the results of individual trials, small group trials and limited field group trials assessed based on assessment aspects and indicators. The results of the assessment aspects obtained will be described as follows.

\section{e. Data Analys is Result of Assessment by Material Experts}

The material expert assessed that the teaching material in the form of a socioculturalbased folklore module for class X at SMA Negeri 1 Percut Sei Tuan which was developed had $93.38 \%$ content eligibility in the "very good" category, $95.19 \%$ presentation feasibility acquisition in the "very good" category, and the acquisition of language eligibility is $94.23 \%$ in he "very good" category.

Based on the average score, it shows that the teaching materials in the form of modules that have been developed with a percentage of the total score of $94.47 \%$ are very good criteria and can meet the demands of learning needs. The results of the average percentage of the aspects of content feasibility, presentation feasibility and language feasibility can be seen in table 6 below : 
Tabel 6. Percentage of Assessment from Material Experts

\begin{tabular}{|l|l|c|c|}
\hline No & \multicolumn{1}{|c|}{$\begin{array}{c}\text { Sub Division of Assessment } \\
\text { Component }\end{array}$} & $\begin{array}{c}\text { Average } \\
(\mathbf{\%})\end{array}$ & Criteria \\
\hline 1 & Content eligibility & 93,38 & Very Good \\
\hline 2 & Serving Feasibility & 95,19 & Very Good \\
\hline 3 & Language Eligibility & 94,23 & Very Good \\
\hline \multicolumn{2}{|r|}{ Average } & $\mathbf{9 4 , 4 7}$ & Very Good \\
\hline
\end{tabular}

The results of the assessment on the sub-components of the suitability of the Core Competencies and Basic Competencies were declared very good with a total percentage of $96.6 \%$ in the "very good" category. The results of the assessment on the material accuracy sub-component were declared "very good" with a total percentage of $93 \%$. The results of the assessment on the material updating sub-component were declared "very good" with a total percentage of $93 \%$. The results of the assessment on the student curiosity sub-component were stated to be "very good" with a total percentage of $100 \%$. The result of the average percentage of all sub-components of the assessment of the content feasibility aspect is 93.38\% with the criteria "very good".

\section{f. Data Analysis of Assessment Results by Design Experts}

Design experts assessed the teaching materials in the form of sociocultural-based folklore modules for class X at SMA Negeri 1 Percut Sei Tuan which were developed to have the feasibility of graphics with an average score percentage of $82.91 \%$. The average percentage results are obtained based on the assessment sub-components in the form of module size, module cover design, and module content design, this can be seen in table 7 below.

Tabel 7. Percentage of Ratings by Design Experts

\begin{tabular}{|l|l|c|c|}
\hline No & \multicolumn{1}{|c|}{$\begin{array}{c}\text { Sub Division of Assessment } \\
\text { Component }\end{array}$} & $\begin{array}{c}\text { Average } \\
(\%)\end{array}$ & Criteria \\
\hline 1 & Module size & 81,25 & Good \\
\hline 2 & Cover design & 81,94 & Good \\
\hline 3 & Design module content & 83,55 & Good \\
\hline Average & $\mathbf{8 2 , 9 1}$ & Good \\
\hline
\end{tabular}

The results of the average percentage shown in the table from the design experts above show that the feasibility test sub-component of the module size has an average percentage of $81.25 \%$, the cover design has an average percentage of $81.94 \%$, content design modules have an average percentage of $83.55 \%$. The percentage result of all the sub-components of the design feasibility test was $82.91 \%$ with "good" criteria. This means that the teaching materials in the form of sociocultural-based folklore modules that have been developed can meet the demands of learning needs.

\section{g. Data Analys is of Individuall Trial Results}

The results of individual trials on students' perceptions of the developed modules showed an average percentage of $72.91 \%$ with the criteria "good enough". Individual trials were carried out to determine students' initial responses as and to identify product deficiencies with products developed prior to small group trials. 
The average percentage results are obtained based on the assessment indicators in the form of material, language, interest in the developed module can be seen in table 8 below.

Tabel 8. Percentage of Individual Trial Results Acquisition of Sociocultural-Based Folklore Teaching Materials

\begin{tabular}{|l|l|c|c|}
\hline No & \multicolumn{1}{|c|}{ Assessment Indicators } & Average (\%) & Criteria \\
\hline 1 & Material & 71,66 & Enough \\
\hline 2 & Language & 70,83 & Enough \\
\hline 3 & Interest & 75 & Enough \\
\hline \multicolumn{2}{|c|}{ Average Amount } & $\mathbf{7 2 , 9 1}$ & Enough \\
\hline
\end{tabular}

The result of the average percentage of the assessment of the material assessment indicator has an average percentage of $71.66 \%$, the language assessment indicator has an average percentage of $70.83 \%$, and the interest assessment indicator has an average percentage of $75 \%$. The result of the average percentage of the whole has an average percentage of $72.91 \%$ with "good" criteria. This means that the sociocultural-based folklore teaching materials that have been developed are in accordance with the needs of students.

\section{h. Data Analysis of Small Group Trial Results}

The results of small group trials about students' perceptions of the modules that have been developed show an average percentage of $84.72 \%$ with "good" criteria. These results were obtained after improvements or revisions from individual trials so that the module was revised again from the material composition and language use that was easier for students to understand. The average percentage results are obtained based on the assessment indicators in the form of material, language, and interest in the developed module can be seen in table 9 below.

Tabel 9. Percentage of Small Group Trial Results Acquisition of Sociocultural-Based Folklore Teaching Materials

\begin{tabular}{|l|l|c|c|}
\hline No & \multicolumn{1}{|c|}{ Assessment Indicators } & Average (\%) & Criteria \\
\hline 1 & Material & 84,44 & Good \\
\hline 2 & Language & 88,88 & Good \\
\hline 3 & Interest & 83,33 & Good \\
\hline \multicolumn{2}{|c|}{ Average Amount } & $\mathbf{8 4 , 7 2}$ & Good \\
\hline
\end{tabular}

The results of the average percentage obtained that the assessment of the material assessment indicators has an average percentage of $84.44 \%$, with the language assessment indicator having an average percentage of $88.88 \%$, and the interest assessment indicator having an average percentage of $83.33 \%$. The result of the average percentage of the whole has an average percentage of $84.72 \%$ with "good" criteria. This means that socioculturalbased folklore teaching materials need to make a few revisions to simplify the language so that it is easier for students to understand so that it can be continued in limited field trials. 


\section{Conclusions}

Based on the formulation, objectives, results, and discussion in the research on the development of sociocultural-based folklore teaching materials for class $\mathrm{X}$ students of SMA Negeri 1 Percut Sei Tuan, which was stated earlier, it can be concluded as follows

1. The sociocultural values contained in the folklore of Putri Hijau and Hikayat Si Khalib include, (1) religious values, (2) solidarity values, (3) unity values, (4) struggle values, and (5) values culture.

2. The module for developing sociocultural-based folklore teaching materials for class $X$ at SMA N 1 Percut Sei Tuan fulfills the requirements and is suitable for use. This is evidenced by the results of the validation of the material eligibility of content experts obtained an average of $93.38 \%$ with the very good category, $95.19 \%$ of the presentation feasibility was obtained with the very good category, and the completeness of the presentation was obtained an average of $94.23 \%$ with the very good category. .

3. The use of sociocultural-based folklore teaching materials (modules) is more effective than the textbooks used by students. This is evidenced by the initial test (pretest) and the final test (posttest) which is carried out to see student learning outcomes. The results of the analysis showed that the pretest mean score (pre-test) was $61.87 \%$ in the sufficient category and the average score (post-test) for the final test was $81.40 \%$ in the good category.

\section{References}

Akbar, S. 2013. Instrumen Perangkat Pembelajaran. Bandung: PT Remaja Rosdakarya.

Arikunto. 2012. Dasar-Dasar Evaluasi Pendidikan (Edisi 2). Bandung : Bumi Aksara.

Arsyad Azhar. 2011. Media Pembelajaran . Cetakan ke-14. Jakarta. PT Rajagrafindo Persada.

Budiningsih, C. Asri. 2003. Perkembangan Teori Belajar dan Pembelajaran Menuju Revolusi-Sosiokultural Vygotsky. Yogyakarta: Jurnal FIP UNY.

Borg, W.R., and Gall, M.D. (1983) Educational Research; An Introduction. Fourth Edition. New York : Longman.

Ghufron, M.Nur. 2013. Teori Vygotsky dan Implikasinya dalam Pendidikan Agama Islam pada Anak. Kediri: Jurnal STAIN Kudus dan STAIN Kediri.

Hurlock, Elizabeth B. 1978. Perkembangan Anak, Jilid 2. Jakarta: PT. Gelora Aksara Pratama.

Kosasi, E. 2014.Jenis-jenis Teks.Bandung:Yrama Widya.

Kemendikbud. 2016. Bahasa Indonesia Ekspresi Diri dan Akademik. Jakarta: Kemendikbud.

Majid, Abdul. 2007. Perencanaan Pembelajaran. Bandung: Remaja Rosda Karya.

Mulyasa.H. 2013. Pengembangan dan Implementasi Kurikulum 2013. PT Remaja Rosdakarya.

Nazila, D.K., Adisaputera, A., and Saragih, A. 2020. Development of Teaching Material for Short Story Writing Experience Based on 7th Grade Students of Junior High School 2 Kejuruan Muda. Budapest International Research and Critics in Linguistics and Education (BirLE) Journal Vol 3 (2): 1137-1150.

Ngalim. 2009. Prinsi-prinsip dan Tehnik evaluasi Pengajaran..Bandung: PT.Remaja Rosdakarya. 
Nugroho, Agung. 2013. Pengembangan Bahan Ajar Sastra Berbasis Cerita Rakyat Musi Rawas Kelas V SD Negeri Karyadadi Kabupaten Musi Rawas. Tesis. Bengkulu: Program Pascasarjana Universitas Bengkulu.

Novianti. 2015. Pengembangan Bahan Ajar Sejarah Berupa Cerita Rakyat Sebagai Wujud Kearifan Lokal. Tesis. Bandarlampung: Program Pascasarjana Unila.

Prastowo, Andy. 2012. Panduan Kreatif Membuat Bahan Ajar Inovatif. Yogyakarta: Diva Press.

Somadayo, S.2011. Strategi dan Teknik Pembelajaran Membaca. Yogyakarta: Graha Ilmu.

Supardi. "Pendidikan Sejarah Lokal dalam konteks Multikulturalisme". (Artikel Jurnal Penelitian) Cakrawala Pendidikan, Februari 2006 Th. XXV, No.1, hal 117-137. Fis Universitas Negeri Yogyakarta.

Sugiyono. 2007. Pengantar Penelitian Pengembangan. Bandung : Remaja Rosdakarya .2013. Metode Penelitian Pendidikan. Bandung : Alfabeta.

Storey, William Kelleher. 2011. Menulis Sejarah: Panduan untuk Mahapeserta Didik. Yogyakarta: Pustaka Pelajar.

Sukmadinata, N., S. 2006. Metode Penelitian Pendidikan. Bandung: Remaja Rosdakarya.

Tarigan, Henry Guntur. 2008. Membaca sebagai Suatu Keterampilan Berbahasa. Bandung: Angkasa.

Tinambunan, Joner. 2016. Pengembangan Bahan Ajar Teks Narasi Sejarah Berbasis Lingkungan Sosial Dan Budaya Simalungun Pada Peserta Didik Kelas V Sdn 091317 Pamatangraya. Tesis. Medan: Program Pascasarjana Unimed.

Trianto. 2009. Mendesain Model Pembelajaran Inovatif-Progresif. Jakarta: Prenada Media Group.

Thiagarajan, S. Semmel, DS. Semmel, M. 1974. Instructional Development for Training Teachers of Exceptional Children. A Sourse Book. Bloomington: Central for Innovation on Teaching The Handicapped.

Trianto. 2010. Mendesain Model Pembelajaran Inovatif Progresif. Jakarta. Kenaba Perdana Media Group.

Rangkuti, N.J., Ansarif, K., and Hadi, W. (2020). The Development of Fantasy Teaching Materials by Using VAK (Visual Auditory Kinesthetic) on 7th Grade Students in SMP Negeri 1 Medan. Budapest International Research and Critics in Linguistics and Education (BirLE) Journal Vol 3 (2): 1170-1181.

Sumayana, Yena. 2017. Pembelajaran Sastra di Sekolah Dasar Berbasis Kearifan Lokal (Cerita Rakyat). Sumedang: Jurnal Program Studi PGSD STKIP Sebelas Maret.

Slameto. 2010. Belajar dan Faktor-Faktor Yang Mempengaruhinya.. Jakarta: Rineka Cipta.

Sudjana, 2002.Metoda Statistika.Bandung: Tarsito

Sudjono,Anas.2010.Pengantar Statistik Pendidikan.Jakarta:Rajawali Pers.

Sugiyono.2010. Metode Penelitian Kuantitatif Kualitatif dan R\&D.Bandung: Algabeta

Sugiyono.2011.Statistika Untuk Penelitian.Bandung:Alfabeta,cv.

Sumiati \& Asra. 2016. Metode Pembelajaran. Bandung: CV Wacana Prima.

Syaodih, Nana. 2015. Pengembangan Bahan Ajar.Medan:Perdana Mulya Sarana.

Tegeh, I Made, dkk. 2014. Model Penelitian dan Pengembangan. Yogyakarta: Graha Ilmu.

Widodo, Chomsin S. dan jasmadi. 2008. Panduan Menyusun Bahan Ajar Berbasis Kompetensi. Jakarta: PT Elex Media Komputindo. 